UDC 811.111'42:341.231.14(4)

DOI https://doi.org/10.32999/ksu2663-2691/2020-81-18

\title{
LEXICAL AND STYLISTIC FEATURES OF JUDGMENTS OF THE EUROPEAN COURT OF HUMAN RIGHTS IN THE ASPECT OF JUDICIAL DISCOURSE
}

\author{
Kapinus Olena Leonidivna, \\ Candidate of Historical Sciences, Associate Professor, \\ Associate Professor of the Department of Foreign Languages № 1 \\ National University "Odesa Law Academy" \\ kapinus_olena@onua.edu.ua \\ orcid.org/0000-0003-4535-8850 \\ Bailo Ivan Yakovlevych, \\ Senior Lecturer of the Department of Foreign Languages № 1 \\ National University "Odesa Law Academy" \\ ivanbailo@onua.edu.ua \\ orcid.org/0000-0002-1953-0023
}

The purpose of the article is to present the results of the study of lexical and stylistic features of English-version court judgments of the European Court of Human Rights in the aspect of judicial discourse. The key task is to determine the level of influence of the revealed lexical and stylistic features on the quality of the legal document and the successful achievement of socially significant communicative goals.

Methods. To achieve this purpose, the authors use general scientific and special linguistic methods of research: the method of generalization, stylistic observation and analysis, and the method of critical discourse analysis.

Results. Based on the analysis of the professional literature, the authors identify the main functional and stylistic characteristics of judicial discourse and inquire into the methods they are implemented in the texts of judgments of the European Court of Human Rights at the lexical level. It is established that the use of terminological vocabulary, in particular of conventional terms, avoids ambiguity and vagueness of statements and promotes the formation of common European standards in the field of human rights. The peculiarities of the use of archaisms in the texts of court judgments and the validity of the use of Latin inclusions are analyzed. It is stated that the court judgment is characterized by clichés and consequently, this peculiarity facilitates accurate and logical presentation of information. It is proved that the judicial discourse, like any other linguistic object dependent on the social environment, strives to maintain a balanced state. On the one hand, it attempts to get rid of obsolete linguistic units that are no longer perceived as necessary by society and to turn to new simplified forms of expression that will be more readily understood by litigants and ordinary citizens. On the other hand, one can observe distinct efforts to preserve certain linguistic features that add the peculiarities inherent only in this type of language to the judicial discourse.

Conclusions. The aforementioned lexical and stylistic features of ECHR judgments are conditioned by the functions which the texts perform in the specific act of linguistic communication in the field of justice. The lexical content of the text directly affects the quality of the court document and accordingly, the respect for the law.

Key words: genre, official business style, language means, texts of court judgments.

\section{ЛЕКСИКО-СТИЛІСТИЧНІ ОСОБЛИВОСТІ РІШЕНЬ ЄВРОПЕЙСЬКОГО СУДУ 3 ПРАВ ЛЮДИНИ В АСПЕКТІ СУДОВОГО ДИСКУРСУ (НА МАТЕРІАЛІ АНГЛІЙСЬКОЇ МОВИ)}

\author{
Капінус Олена Леонідівна, \\ кандидат історичних наук, дочент, \\ доиент кафедри іноземних мов № 1 \\ Національного університету «Одеська юридична академія» \\ kapinus_olena@onua.edu.ua \\ orcid.org/0000-0003-4535-8850
}

Байло Іван Яковлевич, стариий викладач кафедри іноземних мов № 1 Національного університету «Одеська юридична академія» ivanbailo@onua.edu.ua orcid.org/0000-0002-1953-0023

\footnotetext{
Мета статті - представити результати дослідження лексико-стилістичних особливостей англомовних судових рішень Свропейського суду з прав людини в аспекті судового дискурсу. Ключовим завданням $є$ визначення ступеню впливу виявлених лексикостилістичних особливостей на якість юридичного документу та успішність досягнення соціально значущих комунікативних цілей.

Методи. Для досягнення поставленої мети автори використовували загальнонаукові та спеціальні лінгвістичні методи дослідження: метод узагальнення, стилістичні спостереження та аналіз, метод критичного аналізу дискурсу.

Результати. На основі аналізу фахової літератури автори визначили основні функціональні та стилістичні характеристики судового дискурсу і дослідили, як вони реалізуються в текстах судових рішень Європейського суду з прав людини на лексичному
} 
рівні. Встановлено, що використання термінологічної лексики, зокрема конвенційних термінів, дозволяє уникнути багатозначності й розпливчастості висловлень і сприяє формуванню єдиних європейських стандартів в царині прав людини. Проаналізовано особливості уживання архаїзмів в текстах судових рішень та обгрунтованість застосування латинських вкраплень. Зазначено, що судовим рішенням властива клішованість, що сприяє точному та логічному викладу інформації. Доведено, що судовий дискурс, як і будь-який інший мовний об'єкт, залежний від соціуму, знаходиться в прагненні зберегти збалансований стан. 3 одного боку, звільнитися від застарілих лінгвістичних одиниць, які вже не сприймаються суспільством як необхідні, та звернутися до нових спрощених форм висловлювань, які будуть більш зрозумілими для учасників судових процесів і рядових громадян. Однак з іншого боку, спостерігаємо виразне намагання зберегти деякі мовні особливості, які надають судовому дискурсу своєрідності, властивої тільки цьому типу мови.

Висновки. Зазначені лексико-стилістичні особливості судових рішень ЄСПЛ зумовлені виконуваними текстами функціями в специфічному акті мовної комунікації в сфері здійснення правосуддя. Лексичне наповнення тексту безпосередньо впливає на якість судового документа і, відповідно, на повагу до права.

Ключові слова: жанр, офіційно-діловий стиль, мовні засоби, тексти судових рішень.

\section{Introduction}

Judicial discourse is the subject of interdisciplinary research at the intersection of linguistics and law. Moreover, in the judicial discourse both linguists and lawyers analyze identical problems, i.e. linguistic methods, techniques and ways of using the word in the process of administration of justice.

Today, in the genre variety of judicial discourse, texts of judicial acts occupy a special place, since their influence on the life of society and the state gain a special significance. Thus, the judgments of the European Court of Human Rights (here in after ECHR) are binding on the member states of the Council of Europe and as a source of law, compel governments to amend their laws and administrative practices in various fields of activity. Ukraine has adopted the laws "On the enforcement of decisions and application of the practice of the European Court of Human Rights" and "On the Concept of the National Program of Adaptation of the Legislation of Ukraine to the Law of the European Union". They encompass a set of diverse measures aimed at studying and translating European Union legislative and judicial acts and developing a glossary of terms. In this regard, linguistic studies of the texts of contemporary judicial discourse become currently important, including the study of linguistic and stylistic features that ensure the high quality of the judgment, its accessibility, comprehensibility, transparency, clarity, and thorough ordering.

\section{The analysis of recent researches and publications}

A survey of professional literature indicates a steady interest in the problems of judicial communication from the researchers who represent diverse fields of scientific knowledge: the law and jurisprudence (A.S. Pigolkin, I.I. Glovatskyi, Y.P. Zeikan), criminalistics (A.S. Aleksandrov), philosophy (V.S. Bihun), as well as various areas of linguistics. As an object of linguistic research, this sphere of speech activity was analyzed from the standpoint of terminology (I.M. Humovska, E.T. Derdi, N.V. Artikutsa, M. Fischer), translation (Yu.A. Loboda, O.O. Khodakovska, I.A. Semyonkina), discursive theory (L.V. Pravikova, T.V. Dubrovskaya, N.V. Ovchinnikova, O.O. Kobzeva, M.O. Zaitseva, N.Y. Koval, G.V. Karpuk, D. Maynard, D. Kurzon), and others. From the standpoint of stylistics, judicial discourse has been studied by T.V. Gubaeva, T.A. Skuratovska, P. Tiersma, and V. K. Bhatia. It should be noted that, as linguistic material, scholars mainly used court records and oral speeches of lawyers, prosecutors and judges. The most relevant material for the study was the case law of the US courts, while the texts of the judgments of the international courts of the European Union still lack due attention of linguists. It also makes the chosen topic relevant.

The purpose of the article is to identify, in the aspect of judicial discourse, the lexical and stylistic features of ECHR court judgments that affect the quality of the legal document and the successful achievement of socially relevant communicative goals.

The research is based on authentic English texts of European Court of Human Rights judgments, which are available in the HUDOC electronic database on the ECHR's official website (https://www.echr.coe).

\section{Summary of the main research material}

Before proceeding directly to presenting the main results of the analysis of the texts of court judgments we consider it necessary to say a few words about the characteristics of judicial discourse that determine the outline of our study. In the works of many scholars, judicial discourse is looked into as a type of institutional communication whose ultimate goal is to resolve a legal conflict and change the legal situation (Dubrovskaya, 2010: 10). Relations between the participants in the discourse are strictly defined by the rules of the institution of justice, communication being official. This peculiarity influences the choice of linguistic features that are typical of a formal business style. Such linguistic means form a relatively closed system of the language of court documents. The high degree of formality and publicity and pragmatic purpose determine the stylistic features of judicial discourse: ritual, reasoning, logic, correctness and accuracy.

Judgment is a declarative and imperative genre of judicial discourse. The author of this genre is a judge (or a panel of judges). Each court judgment has a wide range of addressees. Firstly, they are litigant parties, both professional lawyers and citizens having no special legal education. Secondly, this is society that assesses the efficiency of the entire justice system by the quality of the judgment. Thirdly, this is other higher or lower courts, which in the course of their activity consider judicial judgments. The diversity of addressees requires the author to use certain language and communication tactics that will make the content of the document accessible and understandable and will provide proofs of the validity and correctness of the judgment made by each of the aforesaid entities.

Let us consider the basic lexical and stylistic features of ECHR judgments that reflect the particularities of judicial discourse and directly affect the success of achieving socially significant goals. 
The specific features of the texts of ECHR judgments are standardization and pattern, which are due to the regularity of communication in the field of justice. The uniform communicative situations that underlie the functioning of the justice institute cause the use of the uniform established verbal formulas - clichés: provided always that; to the extent that; in accordance with the legislation; to declare the application admissible; to restore the applicant's property rights; to execute the warrant, at the material time; available to the Court; the applicant complained under Article...; as can be seen from the case materials; on the basis of the material available to the Court; the Court finds; the Court holds, etc. These clichés are discursive formulas of communication. According to A.A. Zgonnikova, the use of such speech patterns means "saves mental energy, facilitates the rapid and accurate drafting of the document, and helps ease communication" (Zgonnikova, 2014: 35). It is believed that clichés also serve the speed of information transfer.

The ECHR's court judgments set out the verbal formulas rather widely. For example, in the case of Grobelny v. Poland there are 190 uses of word combinations. Approximately the same results were obtained in the study of other court judgments. Obviously, such a high frequency confirms the importance of clichés for the quick, accurate and logical presentation of information, its correct understanding and application. Moreover, the use of established phrases and sentences in court judgments is one means of achieving a socially meaningful communicative goal, i.e. to convince trial participants and the public of justice and impartiality of justice (as noted above). It is the standard statements that deprive the text of the judgment of expressiveness and emotional evaluation, which allows judges to avoid allegations of bias.

Another defining characteristic of the texts of ECHR judgments is their high degree of turning into terminological units. It is evident that the terms in the most concise form (word or word-combination) express a special concept. In addition, within the scope, they are distinguished by: 1) semantic unambiguity, 2) lack of emotional coloring, 3) relative independence from the context, as they are part of a specific term system. Therefore, the use of terminology in ECHR judgments adds accuracy and credibility to the language of the judgment.

Different groups of terms, either legal or non-legal, can clearly be singled out in the documents under consideration. Among the terms of the first group, the terminology of the European Convention on Human Rights, or convention terms hold a special place (e.g. Government, application, applicant, judgment, right to a court, reasonable time, tribunal established by law, normal civic obligations). These terminology units can be divided into two different types: 1) conventional terms not used in other legal contexts (e.g. exhaustion of domestic remedies, just satisfaction, abuse of the right of individual application) and 2) conventional terms used in other legal contexts but in the context of the European Convention they have an autonomous interpretation, i.e. their own interpretation by the European Court of Human Rights (e.g. criminal charge, civil rights and obligations, home, victim, lawful detention). Due to the fact that different legal systems operate in member states of the Council of Europe, the same legal concepts may have different meanings in different states. The principle of autonomous interpretation eliminates such ambiguity in terminology and enables the ECHR to use conventional terms as an effective tool for the protection of fundamental rights and freedoms. Among other things, the application of conventional terms promotes the harmonization of enforcement standards in the member states of the Council of Europe (Fedyk, 2002: 7).

The second group contains the terms that are relevant to the subject matter of the dispute but are not legal. The sectoral affiliation of such terminology is determined by the circumstances of the particular case, such as the occupation of the plaintiff. Thus, in the case of Svanidze v. Georgia, the applicant was charged with medical negligence, which resulted in the patient's death. Accordingly, medical and biological terms are used extensively in the text of the judgment: 'At 3.50 p.m. on 22 September 2005, before the operation started, G.M. died. According to the post-mortem forensic examination, the cause of her death was acute anaemia, which developed as a result of a ruptured fallopian tube caused by an ectopic pregnancy.'

When it comes to court judgments, the use of terminological units is necessary to prevent ambiguity and arbitrary interpretation. However, for an unprepared reader, a text full of highly specialized legal terminology, is difficult to perceive and has the effect of rejection. Hence, there are multiple reproaches that the language of legal documents is irreversible, complex and purely special (Rekosh, 2010).

A notable feature of ECHR judgments is a significant presence of archaisms in the texts (e.g. according to; forthwith; peruse; thence; thenceforth; thereafter; herein; hereinafter, hereof; therefore; whereby; aforesaid, said are used as an article, pronoun or adjective). Such lexical and grammatical filling of documents separates litigation from ordinary life and establishes a certain distance between the discourse participants - agents and clients. However, the use of archaic linguistic means is increasingly criticized. According to some scholars, an outdated vocabulary as well as numerous legal terms, is unnecessary jargon whose primary purpose is to mislead people who do not have a special legal education. Nevertheless, other researchers while rejecting this theory admit that the use of archaic forms is appropriate as long as it does not interfere with the understanding of the content of the document.

We believe that the opinion of the latter is shared by the ECHR judges. They rarely use archaisms, which can cause confusion or make it difficult to understand. For example, the participle aforesaid, by which the persons or objects discussed earlier can be replaced with an article or a pronoun without distortion of meaning, is found in 353 documents, which is only $1.5 \%$ of all English-language judgments posted on the ECHR website. However, archaic forms that standardize the language of the court document and are not critical to comprehension are used much more frequently. Here are examples: the adverb thereafter is used in 2055 judgments $(9 \%)$, whereby - in $2840(12.5 \%)$, hereinafter - in $1448(6.4 \%)$, whereas - in 3387 (15\%), the conjunction provided is found in 3607 texts $(15.9 \%)$ and the word-combination pursuant to - in 14238 (63\%). 
In addition to archaisms, the texts of judgments contain a significant number of Latin inclusions, which are represented by monolexemes (e.g. factum, appendix) and polylexemes (e.g. ab initio, in fine, inter alia, ex post facto, prima facie, locus standi, ratio legis, opinio juris, ex proprio motu, ex lege, malum in se, res judicata, restitutio in integrum, ne bis in idem). It should be noted that the most frequent are the word-combinations, in particular those that consist of a Latin word or expression and an English lexeme, e.g. to apply mutatis mutandis, ad hoc committee, right in rem, incompatible ratione materiae. But lengthier inclusions are also common, such as expressio unius est exclusio alterius; nullum crimen, nulla points sine lege.

Latin terms and phrases give the text of the judgment a special traditional character and persuasiveness. Lawyers are convinced that their proper use underscores the legal validity of the judgment and demonstrates the professionalism of the judges. In addition, Latinisms have long established and clear meaning for professionals, which largely contributes to the uniqueness of the interpretation of the content of the text.

\section{Conclusions}

Thus, the conducted research allows drawing the following conclusions: a court judgment, as an independent genre of judicial discourse, has features due to the diversity of addressees, high degree of formality and publicity, and functional purpose. At the lexical level, these features are manifested in the widespread use of special terms (legal and non-legal), archaisms, and Latinisms. In the context of stylistic specifics, the use of established verbal formulas draws attention. The correct lexical content of the judgment directly affects the quality of the court document and accordingly, the respect for the law and credibility of the entire justice system.

The study presented is only a small part of the complex and painstaking work of analyzing ECHR judgments as the most important human rights protecting body. Since the functioning and existence of ECHR has no analogues in the history of mankind and its activity is considered unprecedented, it cannot be excluded that such an authority will change to find new and more sophisticated forms of work, and at the same time, other ways of expressing them at the linguistic level. Therefore, researchers will be constantly faced with the need to analyze these changes, which leads to further prospects for scientific work.

\section{Bibliography:}

1. Артикуца Н.В. Мова права і юридична термінологія : навч. посіб. Київ : Стилос, 2004. 275 с.

2. Дубровская Т.В. Судебный дискурс: речевое поведение судьи : автореф. дис. ... д-ра филол. наук : спец. 10.02.19 «Теория языка» / Саратовский гос. ун-т им. Н.Г. Чернышевского. Саратов, 2010. 40 с.

3. Згонникова А. А. Клишированные фразы в деловом дискурсе. Профессиональная коммуникация: актуальные вопросы лингвистики и методики. 2014. № 7. С. 32-41.

4. Кравченко С.П. Мова як фактор правоутворення та законотворення : автореф. дис. ... канд. юрид. наук : 12.00 .01$. Одеса, 2000. $20 \mathrm{c}$.

5. Прадід Ю.Ф. Актуальні напрямки досліджень з юридичної лінгвістики. Вісник Одеського інституту внутрішніх справ. Одеса, 2002. № 1. С. 198-204.

6. Рекош К.Х. Язык и право - единый объект юрилингвистики. Вся Европа. 2010, №7-8(46). URL: http://alleuropa. $\mathrm{ru} / \mathrm{p}=2525$ (дата звернення: 20.03.2020)

7. Скуратовська Т.А. Аргументація в американському судовому дискурсі (на матеріалі справ за участю суду присяжних) : дис. ... канд. філол наук : 10.02.04 / Київськ. нац. ун-т імені Тараса Шевченка. Київ, 2002. 196 с.

8. Федик С.Є. Особливості тлумачення юридичних норм щодо прав людини (за матеріалами практики Європейського суду з прав людини та Конституційного Суду України) : автореф. дис. ...канд. юрид. наук : 12.00 .01 / Київ. нац. ун-т ім. Т. Шевченка. Київ, 2002. 20 с.

9. Cabre M.T. Terminology. Theory, methods and applications. Amsterdam Philadelphia : John Benjamins Publishing Company, 1999. $248 \mathrm{p}$.

10. Mellinkoff D. The language of the law. Eugene : Resource Publications, 2004. 526 p.

\section{References:}

11. Artykutsa N.V. (2004) Mova prava i yurydychna terminolohiya [The Language of Law and Legal Terminology]: navch. posib. Kyiv : Stilos, 275 p. [in Ukrainian].

12. Dubrovskaya T.V.(2010) Sudebnyi diskurs: rechevoye povedeniye sudyi [Judicial Dicourse: Behaviour of Judge's Speech]: avtoref. dis. ... d-ra filol. nauk : spets. 10.02.19 "Teoriya yazyka" / Saratovskiy gos. un-t im. N.G. Chernyshevskogo. Saratov, 40 p. [in Russian].

13. Zgonnikova A.A. (2014) Klishirovannyye frazy v delovom diskurse. [Clichéd Phrases in Business Discourse] Professionalnaya kommunikatsiya: aktualnyye voprosy lingvistiki I metodiki. № 7. P. 32-41 [in Russian].

14. Kravchenko S.P. (2000) Mova yak faktor pravoutvorennya ta zakonotvorennya [Language as a Factor of Lawmaking] : avtoref. dys. ... kand. yuryd. Nauk : 12.00.01. Odesa, 20 p. [in Ukrainian].

15. Pradid Yu. F. (2002) Aktualni napryamky doslidzhen z yurydychnoyi linhvistyky [Current Trends in Legal Linguistics Research]. Visnyk Odeskoho instytutu vnutrishnikh sprav. Odesa, № 1. P. 198-204 [in Ukrainian].

16. Rekosh K. Kh. (2010) Yazyk i pravo - yedinyi obyekt yurilingvistiki [Language and Law - a Single Object of Legal Linguistics]. Vsya Yevropa. №7-8(46). URL: http://alleuropa.ru/?p=2525 [in Russian].

17. Skuratovska T. A. (2002) Arhumentatsiya v amerykanskomu sudovomu dyskursi (na materiali sprav za uchastyu sudu prysyazhnykh) [Argumentation in American Judicial Discourse] (on the material of jury trials): dys. ... kand. filol. nauk : 10.02.04 / Kyivsk. nats. un-t imeni Tarasa Shevchenka. Kyiv, 196 p. [in Ukrainian]. 
18. Fedyk S.Ye. (2002) Osoblyvosti tlumachennya yurydychnykh norm schodo prav lyudyny (za materialamy praktyky Yevropeiskoho sudu z prav lyudyny ta Konstytutsiynoho Sudu Ukrayiny) [Peculiarities of Interpretation of Legal Norms on Human Rights (based on the case law of the European Court of Human Rights and the Constitutional Court of Ukraine): avtoref. dys. ...kand. yuryd. nauk : 12.00.01 / Kyiv. nats. un-t im. T. Shevchenka. Kyiv, 20 p. [in Ukrainian].

19. Cabre M.T. (1999) Terminology. Theory, methods and applications. Amsterdam Philadelphia : John Benjamins Publishing Company, $248 \mathrm{p}$.

20. Mellinkoff D. (2004) The language of the law. Eugene : Resource Publications, 526 p.

Стаття надійшла до редакиії 17.04.2020

The article was received 17 April 2020 